\title{
Tartışmacı Tutum Ölçeği Kısa Formunun Türkçe Geçerlilik ve Güvenilirlik Analizi
}

\author{
DOI: $10.26466 /$ opus.480175
}

\author{
Ömer Turunç ${ }^{*}-$ H. Bahadır Eser* - Mehmet Dinç ${ }^{* * *}$ \\ * Doç. Dr, Süleyman Demirel Üniversitesi, İiBF, Isparta / Türkiye \\ E-posta: omert21@hotmail.com_ ORCID: 0000-0003-2234-6523 \\ ** Doç.Dr.Dr. Süleyman Demirel Üniversitesi, İ̈BF, Isparta / Türkiye \\ E-posta: hamza.eser@gmail.com ORCID: $\underline{0000-0003-4063-051 X}$ \\ ${ }^{* * *}$ Dr. Süleyman Demirel Üniversitesi, İ̈BF, Isparta / Türkiye

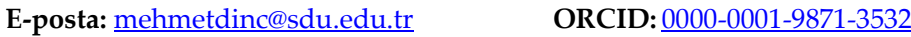

\section{Öz}

Araştırmada orijinal formu 20-maddeli olan, Infante ve Rancer (1982) tarafindan geliştirilen Tartışmacı Tutum Ölçeği'nin kısa formunun Türkçe geçerleme çalışması yapılmıştır. Ölçeğin geçerlilik çalışması beş temel süreç kapsamında yürütülmüştür. Bu süreçler; ölçek belirleme, örneklemin belirlenmesi, tercüme, analiz ile karşılaştırma ve değerlendirme aşamalarından oluşturulmuştur. Bu aşamalarda evrensel ve güncel uygulamalardan yola çıkılarak en etkin analiz ve karşılaştırma yöntemleri kullanılmaya çalışılmıştır. Araştırma Isparta ilinde faaliyet gösteren Süleyman Demirel Üniversitesi İktisadi ve idari Bilimler fakültesinde yürütülmüştür. On bir ayrn bölümde eğitim alan lisans öğrencileriyle anketler yüz yüze uygulanarak veriler toplanmıştır. Kısaltılmış Tartışmacı Tutum Ölçeğinin yapı geçerliliğini test etmek için Brislin ve arkadaşları (1973) tarafindan izlenen yöntem takip edilmiştir. Bu kapsamda ölçek çeviri ve geri-çeviri yöntemiyle Türkçe'ye çevrilmiş ve kadın ( $n=997)$ ve erkek $(n=564)$ toplam 1561 üniversite öğrencisinde uygulanmıştır. Ölçek, iki ayrı örneklemde farklı zamanlarda uygulanan keşfedici ve doğrulayıcı faktör analizleri, içsel tutarlılık analizleri ile karşılaştırmalar yapılarak sınanmıştır. Keşfedici faktör analizi sonucunda hem kadın hem de erkek öğrenci örnekleminde Kısaltılmış Tartışmacı Tutum Ölçeğgi'nin orijinaline uyumlu iki alt boyutlu hali (yaklaşma ve kaçınma boyutu) doğrulanmıştır. Doğrulayıcı faktör analizi sonucunda da kadın ve erkek örneklem grubu katılımcılarında uyum iyiliği değerleri eşik değerler ve üzerinde gerçekleşmiş, bu değerler ölçeğin iki boyutlu yapısını doğrulamıştır. Yürütülen analizler sonucunda 10-maddelik tartışmacı tutum ölçeği kısa formunun güvenilir ve geçerli bir ölçüm aracı olduğu ve yaklaşmacı - kaçınmacı olarak iki alt boyuttan oluştuğu geçerlenmiştir.

Anahtar Kelimeler: Tartışmacı Tutum Ölçeği, Yapı Geçerliliği, Güvenilirlik Analizi, Doğrulayıcı FaktörAnalizi 


\title{
The Analysis of Turkish Validity and Reliability on the Short Version of Argumentativeness Scale
}

\begin{abstract}
In this research, the validation study on the Turkish version of the short form of the Argumentativeness Scale, which is developed by Infante and Rancer (1982), was performed. The validity study of the Argumentativeness Scale was carried out within the scope of five main processes. These processes consist of stages as determining the scale, determining the sample, translating, analyzing, and comparing and evaluating. At these stages, it is tried to use the most effective analysis and comparison methods based on universal and current applications. The study was conducted in Süleyman Demirel University Faculty of Economics and Administrative Sciences in Isparta. In this faculty, face-to-face surveys were conducted with the undergraduate students who were educated in 11 different departments. The scale was applied to two different groups and the validity was determined. The method followed by Brislin et al. (1973) was used to test the construct validity of the short version of Argumentativeness Scale. In this context, scale was translated into Turkish by translation and back-translation method and was applied to a total of 1561 as female $(n=997)$ and male $(n=564)$ a total of 1561 undergraduate students. The scale was tested by using factor analyzes and internal consistency analyzes at different times in two separate samples. As a result of the exploratory and confirmatory analyzes conducted, it was validated that the 10-item argumentativeness scale was a reliable and valid measurement tool and consisted of two sub-dimensions as approaching-avoidant. As a result of the exploratory factor analysis, two sub-dimensions (approaching and avoiding dimension) of the Short Version of Argumentativeness Scale, which were compatible with the original, were confirmed in both female and male students. As a result of confirmatory factor analysis, the goodness of fit values of the female and male sample group were above the threshold values and these values confirmed the two-dimensional structure of the scale. As a result of the analyzes conducted, it was validated that the 10-item argumentativeness scale was a reliable and valid measurement tool and consisted of two sub-dimensions as approaching-avoidant.
\end{abstract}

Keywords: Argumentativeness Scale, Construct Validity, Reliability Analysis, Confirmatory Factor Analysis 


\section{Giriş}

İletişim yazınında bireylerin mesaj alma ve gönderme davranışlarındaki örüntü/kalıp, tutarlılık ve farklılıklar "iletişim kişilik özellikleri" kavramı ile ifade edilmektedir(İnfante, Rancer ve Womack, 2003: 77).Daha özelinde kişilik özellikleri (traits) ise, bireyin düşünme, hissetme veya belli bir biçimde davranmaya yönelik görece tutarlılık arz eden yönelimlerini betimlemektedir.Bireylerarası iletişime odaklanan çalışmalarda kişilik özellikleri kavramsallaştırması ile bireylerin sistematik olarak birbirlerinden farklı oldukları vurgulanmaktadır (Daly, 1987:13-41).

İlgili yazında bazı araştırmacılar (Bayer ve Cegala, 1992:302) iletişim yönelimlerinin, kişilik özelliği yapılarının tersine, mesaj üretiminin daha sınırlandırılmış alanı olmalarından ötürü iletişimsel davranışları incelemede daha uygun olduğunu iddia etmişlerdir. Bu tespitten hareketle, sözlü saldırganlık (verbal aggressiveness) ile tartışmacı tutum (argumentativeness) iletişim yönelimli (kişilik) özellikleri arasında sayılmaktadır.Bu bağlamda bazı insanlar tartışmacı tutum öğelerinin öne çıktığı bir iletişimi benimserken; bazıları ise tam tersine çekinebilir, kendini ifade etmekten geri durabilir. İlk grup bireylerin görüşlerinin başkaları tarafından bilinmesinden haz duydukları, ikinci gruptakilerin ise daha çekimser kaldıkları, tartışmadan uzak durdukları ifade edilebilir (Infante ve Rancer, 1982:72).

Yine insanlar tartışmacı tutumu farklı şekilde değerlendirirler. Tartışmacı tutumları güçlü kişiler tartışmayı, bilgiye ulaşma ve çatışmayı azaltmada bir araç olarak değerlendirirler (Rancer, Baukus ve Infante, 1985:45), tartışmayı eğlenceli ve üretken bir çaba olarak nitelerler (Rancer, Kosberg ve Baukus 1992: 376). Buna karşılık zayıf tartışmacı tutum sahibi bireyler ise tartışmayı, düşmanca ve kötü olarak nitelerler ve tartışmanın her türlüsünden kaçınırlar (Rancer vd., 1985:45).

Tartışmacı tutum olgusu kültürlerarasından (Croucher vd.,2010: 135155) kişiler arasına (Cann vd., 2008: 131-146; Johnson vd., 2011: 214-227) doğru farklı bağlamlarda ve örgütsel ortamlardan (Infante ve Gorden, 1987: 73-80; Infante ve Gorden, 1989: 81-90; Infante ve Gorden, 1991: 294304; Infante vd., 1993: 307-326; Anderson ve Martin, 1999: 21-31)çalışma gruplarına (Limon ve La France, 2005:123-133) kadar farklı düzlem ve düzeyde ele alınmış ve incelenmiştir. 
Tartışmacı tutum genel anlamda sabit bir kişilik özelliği (trait) olarak tanımlanmıştır. Bu kişilik özelliği tartışmacı bireylerin olaylara karşı nasıl tepki verdiğini etkiler, kişiler arası tartışmalara daha fazla katılma ihtimali bulunan, tartışmayı ispatlama ve akıl yürütmede yerleşik hale gelmiş bir etkinlik olarak gören kişileri tanımlar (Infante ve Rancer, 1982: 73; Suzuki, 2011: 125).

Tartışmacı tutum olarak bilinen iletişimci kişilik değişkeni, uluslar arası yazında yaklaşık 36 yıldır eğitim bağlamından romantik ilişkiler, aile iletişimi ve örgütsel iletişim bağlamına kadar geniş bir alanda ilgi çekmektedir. Ancak Türkiye' de örgütsel davranış araştırmalarında tartışmacı tutum özelinde görgül çalışmaların yapılabilmesinin yolu bu konuda psikomotrik yeterliliğe sahip uygun ölçeklerden geçmektedir.Söz konusu gereklilikten yola çıkarak bu çalışmanın amacı, orijinali 20-maddeli olan, Infante ve Rancer (1982: 72-80) tarafından geliştirilen, Türkçe geçerlilik ve güvenilirlik çalışması ise Kaya ve Kılıç (2008: 87-95) tarafından gerçekleştirilen Tartışmacı Tutum Ölçeği'nin 10-maddelik kısa versiyonununTürkçeye ve Türk kültürüne uygun olup olmadığını uyarlayarak geçerlemesini sınamaktır.

\section{Kavramsal Çerçeve}

Kavramsal çerçeve başlığı altında, tartışmacı tutum kişilik özelliğinin ne anlama geldiği, bu özelliği yüksek ve düşük düzeyde davranışlarına yönlendiren kişilerin birbirinden farklılıklarının neler olduğu, tartışmacı tutumlar ile benzerlik gösteren değişkenlerin neler olduğu ve bu tutumun ölçülmesine yönelik olumlu ve olumsuz bakış açılarının kümelendiği yazına yer verilecektir.

\section{Tartışmacı Tutum Kavramı}

İletişim olgusu literatürde oldukça geniş boyutlu bir kavram olarak ele alınmaktadır. Bu bağlam içinde alt boyutlardan bir tanesi de tartışma kavramıdır. Akıl yürütme ve karar vermeyi içeren niyetli bir etkinlik olan (Stewart ve Roach, 1998:178) tartışma, düşüncenin gelişmesi için hayati öneme sahiptir. Tartı̧̧ma kavramı tartışmacı tutum olgusunun merkezinde ve ikna sürecinin özünde yer alan bir kavramdır (Rancer, 
2004:126). Tartışma insanların göreceli gerçekliklerinin, benimsedikleri değer yargılarının veya eylem ve pratiklerinin üzerinde anlaşma sağlanmış veya tartışmalı konulara dair müzakere sürecinde, mantıksal yoldan sonuca varmada ve mantık yürütmede kendini gösteren gözlemlenebilir etkileşim örüntüsü olarak tanımlanabilir (Seibold ve Meyers, 1986:147).

Infante ve Rancer (1982:72-80) tartışma olgusunu bilimsel bir bakış açısı ile ele alarak psikoloji odaklı bir yaklaşımın öncüsü olmuşlardır. Psikolojik yaklaşım bireyin güdü ve algılarını kullanarak tartışmayı nasıl anlamlandırdığı ve çevresinde ortaya konan tartışmacı öğeler içeren iletişimi nasıl değerlendirdiği üzerine odaklanır (Rancer, Baukus ve Infante, 1985: 37).

Tartışmacı tutum, bir bireyin iletişim sürecinde tartışmalı konulara ilişkin kendi pozisyonunu savunmak ve bu konularda karşı tarafın sahip olduğu konumu veya duruşu sözel olarak hedef almak amaçlı yatkınlığını temsil eden sabit bir kişilik özelliğiniifade eder (Infante ve Rancer, 1987:72). Bazı çalışmalarda tartışmacı tutum bireyin; tartışmalı bir konuda karşısındaki kişinin konumunu çürütmeye çabalarken kendi konumunu, duruşunu sunma ve savunma eğilimi (Infante, Rancer ve Womack, 2003: 94, Rancer, 1998: 152) anlamında kullanılmıştır.

Üzerinde söz birliği olmayan tartışmalı konuların dile getirildiği ortamlarda görülen bir kişilik yapısı olarak kabul edilen (Infante ve Rancer, 1982:72) tartışmacı tutum yapıcı bir (kişilik) özelliği olarak da ifade edilir. Öğrenme üzerindeki olumlu etkisi, empatik öğeler içermesi, kişinin kendi benliğinin yanında karşısındakinin de benliğini dikkate alması, düşünme ve problem çözme becerilerini geliştirmesi, grup içinde güvenilirliği artırması, lider özelliklerini öne çıkarması,iletişimi daha nitelikli hale getirmesi, örgütsel iletişim üzerinde olumlu etki ortaya çıkarmakapasitesi söz konusu yapıcı kişilik öğesinin bileşenleri olarak sayılabilir (İnfante, 1989: 159).

Tartışmacı tutumun ilgili yazında ayrıca "saldırgan davranışlar" kavramıyla da ilişkilendirildiği görülmektedir. Bu değerlendirmenin temelinde Infante (1988:6-7) tarafından geliştirilen "kişilerarası iletişimde saldırganlıkmodeli" yer almaktadır. Infante'ye göre saldırganlık fiziki ve sembolik olmak üzere iki şekilde ortaya çıkar. Saldırganlık yapıcı ve yıkıcı öğelere sahiptir. Yapıcı öğeler tatmini artırarak kişilerarası ilişkilerleri 
geliştirmekte iken, yıkıcı öğeler tam tersi tatmini azaltmakta ve ilişkileri zayıflatmaktadır. Kişiler arası şakalaşma, sportif rekabet, yapıcı fiziki saldırganlığa, kişilere yönelik fiziki şiddetise yıkıcı fiziki saldırganlığa örnek olarak gösterilebilir. İnfante, sözlü ve sözsüz kanalların kullanımına odaklanan sembolik saldırganlığı modelinin merkezine yerleştirmektedir. Sembolik saldırganlık en düşük düzeyde kişinin domine edilmesinden bireyin benlik algısına yönelik saldırılara kadar farklı düzlemlerde ortaya çıkabilmektedir. Saldırgan kişilik ikisi yıkıcı ve ikisi yapıcı olmak üzere dört yönlü bir yapı sergiler. Bu bağlamda kişiliğin saldırgan yönü atılganlık (assertiveness) ve tartışmacı tutumdan (argumentativeness), yıkıcı yönü ise düşmanlık (hostility) ve sözlü saldırganlıktan (verbal aggressiveness) oluşmaktadır (Infante, 1988:7) .

$\mathrm{Bu}$ model içinde tartışmacı tutum atılganlığın bir alt boyutu olarak değerlendirilir. Çünkü tartışma iletişimci kişilik açısından atılganlığ temsil eder. Bununla birlikteher atılgan davranış tartışmacı öğeler içermeyebilir. Atılganlık ve tartışmacı tutum özellikleri yapıcı olarak düşünülse de, bu özelliklerin kimi zaman yıkıcı sonuçları da olabilir. Örnek vermek gerekirse bir kişi diğerini incitme amaçlı atılgan olabilir veya diğer bir kişiyi huzursuz etme amaçlı tartışmacı olabilir. Ancak bu iki özellik kişilerarası etkileşimleri artırabilme potansiyelleri sayesinde genelde yapıcı iletişim bağlamında ele alınırlar (Infante, 1987: 164).

\section{Güçlü ve Zayıf Tartışmacı Tutumlara Sahip Bireyler Arasında görülen Farklar}

Güçlü tartışmacı tutumlara sahip bireylerin tartışmadan kaçınma motivasyonlarının düşük, tartışmaya meyilli olma güdülerinin ise yüksek olduğu öne sürülmektedir (Hamilton ve Mineo, 2002: 283). Bu tip bireylerin tartışılan konulara daha ilgili, daha dinamik, daha bilgili ve becerili olarak değerlendirildiği görülmüştür (Terlip, 1989:40). Yine güçlü tartışmacı tutumları olan bireylerin sosyal, siyasal, etik ve kişisel davranışlar gibi konularda tartışmaya daha fazla meyilli oldukları görülmüştür (Infante ve Rancer, 1993:331).

İkna alanında yapılan araştırmalar, güçlü tartışmacı tutumları olan bireylerin karşısındakini ikna etmeye yönelik motivasyonlarının, düşük tartışmacı tutum düzeyine sahip bireylere nazaran daha güçlü olduğunu 
göstermiştir (Infante, Step ve Horvarth, 1997: 80). Yine bu tip bireylerin iletişimde tartışmacı öğelerin kullanılmasından daha az kaygı duydukları, tartışmayı heyecan verici entelektüel bir eylem olarak değerlendirdikleri görülmüştür (Rancer ve Avtgis, 2006: 17).

Zayıf tartışmacı tutumlara sahip kişilerin yukarıdaki bireylerin aksine tartışmadan kaçınma motivasyonlarının yüksek, tartışmaya meyilli olma güdülerinin ise zayıf olduğu görülmüştür. Bu bireyler tartışmacı davranışa ilgisizdirler, tartışmadan kaçınırlar. Tartışmalı bir konu ile karşılaştıklarında, tartışma konusundan uzaklaşıp konuyu sosyal ve duygusal sorunlara çevirmeye eğilimlidirler. Tartışmaya ikna edildiklerinde dahi iletişim esnasında memnun olmadıkları hususları ifade etmekten çekinirler. Güçlü tartışmacı tutumlara sahip bireylere nazaran bu kişiler, iletişim esnasında gereksiz cümleleri daha az kullanırlar. Huzursuz olmaktan kaçındıkları için tartışmalı konular hakkında konuşmaktan çekinirler (Infante, 1981: 270; Rancer ve Avgtis, 2006:17).

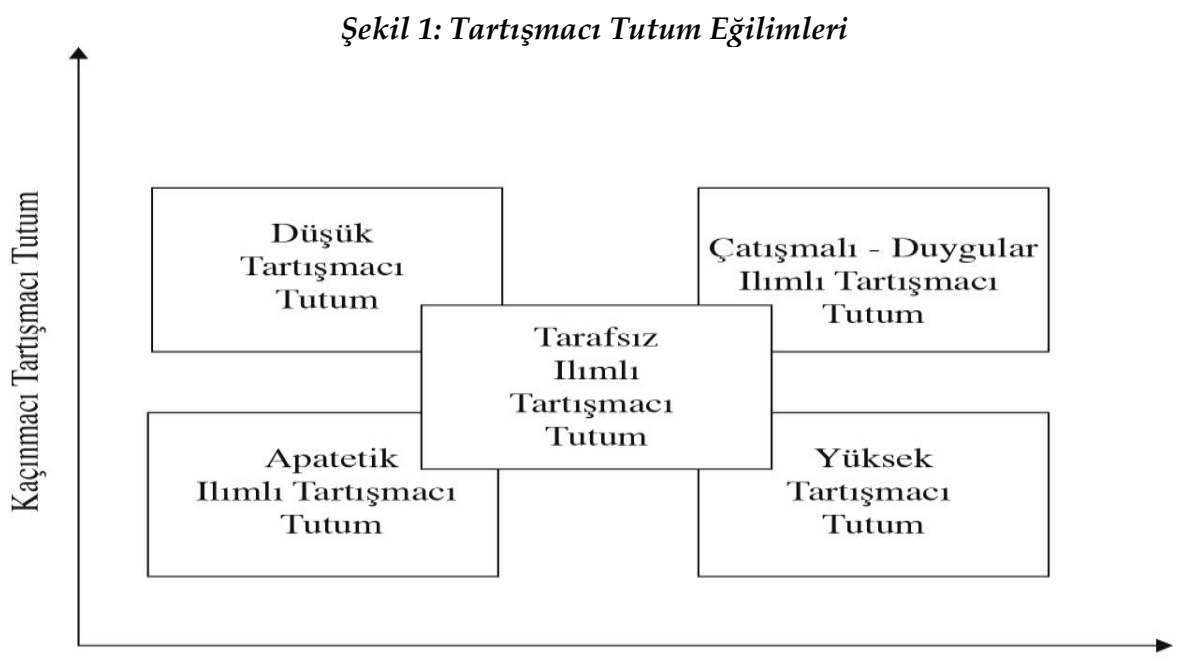

Yaklaşmac1 Tartışmac1 Tutum

Kaynak: Alcala, Cristina Gonzalaez, 2012: 63, Rancer ve Avtgis, 2006: 17'den uyarlamıştır.

Güçlü ve zayıf tartışmacı tutumlara sahip bireyler yanında bir de ortalama tartışmacı tutumlara sahip bireyler vardır. Bu bireyler "çelişen duygular" yaşarlar. Başarılı olabileceklerine inandıklarında tartışmaya 
girerler. Dördüncü tip tepkisiz (apetetik) 1lımlılar olarak ifade edilebilir. Bu kategorideki bireyler tartışmaya karşı olumlu ya da olumsuz bir tavır içinde olmazlar, ancak zorunda kaldıklarında tartışmaya girerler (Rancer ve Avtgis, 2006:153; Hamilton ve Mineo, 2002: 288). Son olarak 1lımlı kategori içinde sayılabilecek "yansız 1lımlılar" vardır. Bu gruba giren bireyler, tartışmaya girme ve çekinme motivasyonları açısından ölçülü olan bir tutum ortaya koyarlar (Hamilton ve Mineo, 2002: 289). Beş kategoride ifade edilen tartışmacı tutumların sınıflandırılması Şekil 1'de gösterilmiştir.

\section{Tartışmacı Tutum ve İlgili Diğer Yapıların Kıyaslaması}

Tartı̧̧macı tutum ve sözlü saldırganlık içeren kişilik özellikleri, iletişimin saldırgan biçimleri olarak kabul edilmesi noktasında benzeşirler. Ancak bu iki kavram, birçok bakımdan farklılık gösterir. Yukarıda girişte de kısaca değinildiği üzere, tartışmacı tutum bir bireyin iletişim sürecinde tartışmalı konulara ilişkin kendi pozisyonunu savunmak ve bu konularda, karşı tarafın sahip olduğu konumu veya duruşu sözel olarak hedef almak amaçlı yatkınlığını ifade eder (Infante ve Rancer, 1982: 72). Buna karşın sözlü saldırganlık ise, muhatabını küçük görerek sözlü sataşmayı, provoke etmeyi, karşıdaki kişiyi küçük düşürme ve onun özimajına zarar verme eğilimini ifade eder. Kişisel üstünlüklerini zorlayarak gösterme hali, karşıllıkı iletişimde hakimiyet kurma güdüsü, saldırgan tavırlar sergileyerek gerginlik oluşturma refleksleri sözlü saldırganlık eğilimi güçlü olan bireylerin motivasyon kaynakları olarak sayılabilir (Infante ve Wigley, 198: 61). Tartışmacı tutum sonuçlarının olumlu ve sözlü saldırganlık sonuçlarının tümünün ise olumsuz olması, tartışmacı tutum ve sözlü saldırganlık (İnfante ve Rancer, 1996:327) içeren kişilik özellikleri arasındaki bir diğer farklılıktır.

\section{Tartışmacı Tutumun Ölçülmesi}

Tartışmacı tutumun ölçülmesi özünde, tartışmadan zevk alan onu iyi bir fiil olarak değerlendirenler ile tartışmadan hoşlanmayan veya başarılı olmayan kişilerin davranışlarını ve sonuçlarını anlama arayışının bir sonucudur (Rancer ve Avtgis, 2006:39).Tartı̧̧macı tutumu değerlendirmede 
başat sorun alanının ölçüm konusuna odaklandığı görülmektedir. Bu sorun iki temel bakış açısının karşı karşıya gelmesinden kaynaklanmaktadır. $\mathrm{Bu}$ bakış açlarından ilki bir bireyin niyet ve davranışları onun tartışmacı tutum düzeyine ilişkin bir bakış açısı verebilir mi sorusuna cevap ararken diğer bakış açısı ise bireyin çevresindekiler tarafından nasıl algılandığı hususunun onun tartışmacı tutum düzeyine ilişkin bir referans noktası sağladığını iddia etmektedir. Bu iki değerlendirme de yukarıda işaret edilen söz konusu ölçüm zorluğuna işaret etmektedir (Croucher vd.,2017:24).

Tartışmacı tutum konusuna ilgi duyan araştırmacılar genellikle bu olguyu ölçmek için Infante ve Rancer (1982:72-80) tarafından geliştirilen 20 maddeli Tartışmacı Tutum Ölçeği'ni kullanmaktadırlar. Ancak ilgili yazında öne çıkan bazı araştırmacılar (Kotowski vd., 2009: 444-445), bu ölçeğin kapasitesinin sınırlı bir düzeyde kaldığını da iddia etmektedirler. Bu doğrultuda kişinin kendisine ilişkin öz değerlendirmeleri (self-report) ve çevresindeki kişiler tarafından ortaya konan davranışsal değerlendirmeler arasında çok küçük bir korelasyon diğer bir ifade ile benzerlik olduğu öne sürülmüştür. Yine bu bağlamda tartışmacı tutum ölçeğinin öz-değerlendirme / öz-bildirim tutum ölçekleri olarak ve tartışmacı tutuma yönelik davranışsal eğilimleri ortaya koymada yetersiz kaldığı vurgulanmaktadir.

Bu eleştirilere karşın Infante ve arkadaşları (2011: 146-152) yaptıkları yazın taramasında, ölçeğin akademik mecralar ile paylaşımından günümüze yaklaşık 100 çalışmada kullanıldığını, kişinin öz- değerlendirmeleri üzerinden tartışmacı tutum eğilimini ölçen bu ölçek ile elde edilen bulguların ölçeklerinin yapısal geçerlilik ve güvenilirliğini teyit ettiğini vurgulamışlardır.

$\mathrm{Bu}$ savunmaya karşın, tartışmacı tutum ölçeği halihazırda yapısal geçerlilik eksikliği, faktör dağılımları arasında tutarsız ilişkiler sergilediği ve yalnızca kişisel öz-değerlendirme üzerinden ölçüme odaklandığı hususlarında eleştirilmektedir (Kotowski vd., 2009: 444-446; Levine ve Kotowski, 2010: 68). Infante ve Rancer (1982:72-80) tartışmac1 tutum ölçeğinin "yaklaşma" ve "kaçınma" şekilde iki alt boyuta sahip olduğunu iddia ederken diğer bazı araştırmacılar (Hamilton ve Mineo, 2002: 300; Kotowski vd.,2009: 450) sorunlu maddeler çıkarıldığında ölçeğin iki 
boyutlu olmaktan çıkıp tek boyutlu hale dönüştüğünü ortaya koymuşlardır.

Özellikle Hamilton ve Mineo (2002: 300), meta-analiz tekniğini kullanarak Tartışmacı Tutum Ölçeği'nin orijinalindeki gibi iki boyuttan ve hatta daha fazla boyuttan $\mathrm{m}$ ı yoksa tek boyuttan $\mathrm{m}$ i oluştuğunu incelemiştir. Birçok meta-analiz çalışmaları sonucunda araştırmacılar; yaklaşmacı ve kaçınmacı tartışmacı tutum boyutlarının Infante ve Rancer'in (1982) orijinal ölçek geliştirme raporunda önerdiği gibi birbirinden bağımsızboyutlar olmasından ziyade negatif korelasyona sahip olduğunu iddia etmişler ve bulgularını ölçeğin tek boyutlu olduğuna kanıt teşkil ettiğini belirtmişlerdir. Bununla birlikte Hamilton ve Mineo (2002: 295-296) tartışmacı tutum ölçeğinin altı veya yedi farklı içerik temasından veya boyuttan oluşabileceğini öne sürmüştür. Onlara göre ölçek; tartışmacı tutum becerisi (madde 16 ve 18), düşmanlık veya suç (madde 1 ve 5), meraklılık (madde 2 ve 15), rekabetçilik (madde 4, 7, 9, 11, 13, 17 ve 20), sonuçlara dair kaygı (madde 3, 6, 8, 10 ve 12) ve aktif kaçınma veya geri çekilme (madde 14 ve 19) boyutlarından oluşmaktadır.

Yine Blickle (1995: 104) tartışmacı tutum ölçeğinin orijinalindeki 20maddesini tekrar faktör analizine tabi tutmuş, "tartışmacı tutum becerilerinin öz-değerlendirmesi" adını verdiği madde 16 ve 18'in oluşturduğu bir başka faktör elde etmiştir. Bu şekilde Blickle (1995: 108), Tartışmacı Tutum Ölçeği'nin; yaklaşmacı, kaçınmacı tartışmacı tutum ve kendisinin keşfettiği tartışmacı tutum becerisi olmak üzere üç boyuttan oluşabileceğini açılamıştır. Bulduğu bu tartışmacı tutum becerisi boyutunun yaklaşmacı tartışmacı tutum boyutuyla güçlü ve pozitif yönlü, kaçınmacı tartışmacı tutum boyutuyla ise güçlü ve negatif yönlü bir ilişki gösterdiğini ifade etmiştir.

İnfante ve Rancer (1982:72-80) tartışma konusunda kişisel farklılıklara işaret eden yüksek, orta ve düşük düzeydeki güdülemeyi tanımlamak amacıyla "Tartışmacı Tutum Ölçeği"'ni geliştirmiştir. Ölçeğin geçerliliğini sağlamak adına araştırmacılar pek çok geçerlilik testi uygulamıştır. Bu testlerden birinde İnfante ve Rancer, tartışmacı tutumun bireyin iletişim kurma yönelimiyle ilişki gösterip göstermediğini değerlendirmiştir. Bu amaçla tartışmacı tutum ölçeği ve iletişimsel yönelimlerin diğer ölçümleriyle (Mc Croskey'nin Kişisel İletişim Kaygı Bildirimi -PRCA- ölçeği gibi) 
44 öğrenci üzerinde bir çalışma kurgulamıştır. Bu testin sonuçları araştırmacıların beklentilerle tutarlılık göstermiştir. Bu sonuçlara göre, katılımcıların tartışmacı tutumlarının yaklaşmacı alt boyut puanları PRCA puanlarıyla anlaml, orta düzeyde ve olumsuz bir ilişki gösterirken, kaçınmacı alt boyutları ise anlamlı ve pozitif bir ilişki sergilemiştir.

İnfante ve Rancer (1982: 77-78) tartışmacı tutum ölçeğinin yakınsama (convergent) ve uzaksama (divergent) geçerliliğini yine davranışsal bir tercih çalışması yürüterek değerlendirmiştir. 51 öğrenciden oluşan farklı bir örnekleme tartışmacı tutum ölçeğini uygulamıştır. Bir hafta sonra katılımclara, araştırmanın sonuçlanması adına gerekli işlemleri yapmak amacıyla dört çalışmadan hangisine katılmak istediklerini sorularak her birinin kısa bir tarifi kendilerine okutulmuştur. Bu çalışmalar; yakın bir arkadaşıyla tartışmalı bir konuda tartışmak, televizyon programlarını izlemek ve derecelendirmek, hayatın amaçlarına dair bir öğrenciyle sohbet etmek ve kendi seçtikleri bir konuda topluluk önünde bir konuşma yapmak şeklinde düzenlenmiştir.Daha sonra katılımcılardan yedi dereceli bir ölçek üzerinde çalışmaya katılımlarını veya kaçınmalarını belirtmeleri istenmiştir. Çalışma sonunda araştırmacılar, tartışmacı tutumun yaklaşmacı alt boyutu ile tartışmaya katılma isteği arasında pozitif, tartışmadan kaçınma isteğiyle negatif bir ilişki tespit etmişlerdir. Tam tersine tartışmacı tutumun kaçınmacı alt boyutu ile tartışmaya katılma isteği kendi arasında negatif, tartı̧̧madan kaçınma isteğiyle ise pozitif bir ilişki göstermiştir. Tartışmacı tutumun yaklaşma ve kaçınma alt boyutları ile diğer iki konuya katılma ve kaçınma arasında herhangi bir ilişki tespit edilememiştir.

Tartışmacı tutum ölçeğininpek çok farklı dile ve kültüre çevrilerek uyarlama çalışmaları yapılmıştır. Ölçek alanda uzun denilebilecek bir süredir kullanılmaktadır. Uyarlama çalışmaları yapılan dil ve kültürler arasında Çince, Fince, Fransızca, Almanca, Yunanca, Japonca, Korece, Romanca, Slovakca ve Taice öne çıkanlarıdır (Rancer ve Avtgis, 2006:43). Bu ölçeğin 20-maddeli versiyonu Türkçe'ye ve Türk kültürüne sadece birkaç çalışmada (Kaya ve Kılıç, 2008: 87-95; Öztürk, 2013: 1-118) çevrilmiştir. Ancak tartışmacı tutum ölçeğinin 10-maddeli kısa formuyla ilgili herhangi bir geçerlilik ve güvenilirlik çalışmasına ulaşılamamıştır. 
Tartışmacı tutum konusunu merkezealan çalışmaların ekseriyetinin Birleşik Devletler'de yürütüldüğü görülmektedir. Ölçek kültürlerarası araştırmalarda da ilgi görmektedir.Örneğin Avtgis ve Rancer (2002: 191200) tartışmacı tutum ve sözlü saldırganlık özelliklerini Birleşik Devletler, Avustralya ve Yeni Zelanda kültürlerinde; Suzuki ve Rancer (1994: 256279) Japon kültüründe; Avtgis ve arkadaşları (2008: 17-24) ise Bulgaristan kültüründe kavramsal ve metodolojik eşdeğerliğini etik bir yaklaşım temelinde test etmişlerdirTüm bu çalışmalar tartışmacı tutum ve sözlü saldırganlık yapılarının ve ölçüm farklılıklarının farklı kültürlerde eşdeğer olduğunu teyit etmiştir.

\section{Yöntem}

Tartışmacı Tutum Ölçeğinin geçerlilik çalışması beş temel süreç kapsamında yürütülmüştür. Bu süreçler; ölçek belirleme, örneklemin belirlenmesi, tercüme, analiz ile karşılaştırma ve değerlendirme aşamalarıdır. Bu aşamalarda evrensel ve güncel uygulamalardan yola çıkılarak en etkin analiz ve karşılaştırma yöntemleri kullanılmaya çalışılmıştır.

\section{Ölçüm Aracı}

Ölçümlerle ilgili araştırmada yaşanan genelleştirilmiş hatayı ifade eden varyans hatası ihtimalinden ve katılımcıların yorgunluğundan kaçınmak amacıyla bazı araştırmacılar Tartışmacı Tutum Ölçeği'nin kısa versiyonunu geliştirmişlerdir. Infante ve Gorden (1989: 81-90) tarafından oluşturulmuş Kısaltılmış Tartışmacı Tutum Ölçeği, 5'li Likert türü derecelendirmeye sahip 10 maddeden oluşmaktadır (Rancer ve Avtgis, 2006: 263-264). Ölçeğin bu kısa formu tartışmacı iletişimi örgütsel bağlamda (Infante ve Gorden, 1989: 81-90; 1991: 294-304; Anderson ve Martin, 1999: 2131), aile iletişimi bağlamında (Martin ve Anderson, 1997:299-314) ve eğitimsel iletişim bağlamında (Myers ve Knox, 2000: 299-309; Myers ve Rocca, 2000: 1-12) inceleyen araştırmalarda başarıyla kullanılmıştır.

Tartışmacı Tutum Ölçeği'nin 10 maddelik kısa sürümü kullanan çalışmalarda Crombah alfa güvenilirlik katsayısı Infante ve Rancer (1982) tarafından .73; Martin ve Anderson(1997) tarafından .80 ve Myers ve Knox (2000) tarafından .86 olarak bulunmuştur. Yapılan pek çok çalışmada 
güvenilirlik katsayısı .70-.85 arasında belirlenmiştir (Anderson ve Martin, 1999; Myers, 1998; Myers \& Rocca, 2000)

\section{Örneklem}

Araştırma verileri Isparta ilinde faaliyet gösteren Süleyman Demirel Üniversitesi İktisadi ve idari Bilimler fakültesinde toplanmıştır. 2015-2016 Bahar döneminde örgün eğitim gören Lisans öğrencilerinin 1. ve 2 . öğretiminde 11 ayrı bölümde eğitim alan öğrencilerle yüz yüze yapılan anketlerle veriler toplanmıştır. SDÜ İ̈BF de tüm birimlerde yaklaşı 10000 öğrenci eğitim görmektedir. Ölçek iki ayrı kitleye uygulanarak geçerlilik belirlenmeye çalışılmıştır. Bu bağlamda mevcut evrende öğrenciler kadın ve erkek gruplarına ayrılarak uygulama yapılmıştır.

İlk grup olan kadın öğrencilerde ( Evrenin yaklaşık \%50 sini oluşturduğu değerlendirilerek) ana kütleden $\% 95$ güvenilirlik sınırları içerisinde \%5'lik bir hata payı dikkate alınarak örneklem büyüklüğü 357 kişi elarak hesaplanmıştır (Yazıcıoğlu \& Erdoğan, 2007). Yapılan anketlerden 1000'ü geri dönmüştür. Yapılan uç değer (outliers) analizinde değişkenlere ait normal dağılımı bozan 3 adet veri seti, analizden çıkartılmış ve toplam 997 adet anket analizlere dâhil edilmiştir. Kız öğrencilerin \%58'i I. öğretim, $\% 42$ 'i II. öğretimde eğitim görmektedir. Öğrencilerin \%36,6'si 1 . Sınıf, $\% 27,7$ 's 2 sınıf, \%15,1 i 3. Sınıf, \%20,6 sı ise 4. Sınıfta eğitim görmektedir.

İkinci grup olan erkek öğrencilerde ( Evrenin yaklaşık \%50 sini oluşturduğu değerlendirilerek) ana kütleden $\% 95$ güvenilirlik sınırları içerisinde $\% 5$ 'lik bir hata payı dikkate alınarak örneklem büyüklüğü yine 357 kişi elarak hesaplanmıştır (Yazıcıŏlu \& Erdoğan, 2007). Yapılan anketlerden 684'ü geri dönmüştür. Yapılan uç değer (outliers) analizinde değişkenlere ait normal dağılımı bozan 20 adet veri seti, analizden çıkartılmış ve toplam 564 adet anket analizlere dâhil edilmiştir. Erkek öğrencilerin \%49,2'i I. öğretim, \%50,8'i II. öğretimde eğitim görmektedir. Öğrencilerin \%38,7'si 1. Sinıf, $\% 27,3$ 'ü 2 sinıf, $\% 16,1$ i 3. Sınıf , $\% 17,9$ u ise 4 . Sinıfta eğitim görmektedir.

\section{Tercüme}


Infante ve Gorden (1989: 81-90) tarafından oluşturulan ve pek çok yabancı araştırmacı tarafından farklı alanlarda kullanılan kısaltılmış Tartışmacı Tutum Ölçeğinin yapı geçerliliğini test etmek için Brislin ve arkadaşları (1973) tarafından izlenen yöntem takip edilmiştir. Bu yöntem hedef dile çeviri, hedef dile yapılan çevirinin değerlendirilmesi, kaynak dile tekrar çeviri, kaynak dile yapılan tekrar çevirinin değerlendirilmesi ve uzmanlarla son değerIendirme aşamalarından oluşmaktadır. Tercüme ölçeğin orijinalinden alan uzman ve İngilizce yeterliliğe sahip yerli ve yabancı üç akademisyen tarafından tercüme geri tercüme yöntemiyle hatalar giderilerek dört geri besleme süreciyle usulüne uygun şekilde tamamlanmıştır. Ölçek olumlu ve olumsuz ifadeler içermektedir. Uygulamada yanlış anlamalara yol açabilecek tercüme hatalarını minimize etmek maksadıyla, süreç hassasiyetle yürütülerek orijinali ifade eden Türkçe ölçek oluşturulmuştur(Bkz.Ek:1).

\section{Analiz ve Bulgular}

$\mathrm{Bu}$ aşama ölçeğin geçerlik ve güvenirlilik analizlerinden oluşmaktadır (Hinkin, 1995). Bu kapsamda ölçeği değerlendirirken genellikle faktör analizleri, içsel tutarlılık analizleri, test-tekrar test analizleri ve yakınsak geçerlilik analizleri kullanılmaktadır. Bu çalışmada iki ayrı örneklemde ayrı zamanlarda uygulanan faktör analizleri ve içsel tutarlılık analizleri ve test tekrar test analizleri ile karşılaştırmalar yapılarak ölçek geçerleme çalışması tamamlanmaya çalışılmıştır.

Araştırma kapsamında öncelikle keşfedici faktör analizi yapılmıştır. Keşfedici faktör analizinden önce örneklem sayısının yeterli olup olmadığı Kaiser-Meyer- Olkin (KMO) katsayısı, maddeler arasındaki korelasyonun uygun olup olmadığını ise Barlett testi ile incelenmiştir. Genellikle KMO katsayısının, 60' dan büyük olması beklenmektedir ve ,80'in üstündeki değerler çok iyi olarak kabul edilmektedir (Tabachnick \& Fidell, 2012). Ayrıca Barlett testi sonucunda anlamlı çıkması beklenmektedir. Yapılan analizler,kadın ve erkek gruplar için Kaiser-Meyer-Olkin değerininsırasıyla.75 ve .77 olduğunu ve Barlett testinin ise sirasıyla $[\chi 2=1607$, $\mathrm{df}=45, \mathrm{p}<, 000)]$ ve $[\chi 2=911, \mathrm{df}=45, \mathrm{p}<, 000)]$ seviyesinde anlamlı olduğunu göstermektedir. 
$\mathrm{Bu}$ aşamadan sonra Promax eksen döndürme tekniği uygulanarak keşfedici faktör analiz (KFA) yapılmıştır. Yapılan faktör analizi sonuçları incelendiğinde özdeğeri 1'den büyük olan iki boyutun toplam varyansın kadın ve erkek gruplar için sırasıyla \% 44,2 ve \%45,2'sini açıkladığı görülmüştür. Boyutlara göre faktör yüklerini içeren yapı matrisi ve ölçekteki her bir maddeye ilişkin ortalama ve standart sapma değerleri Tablo 1 ve 2 'de verilmiştir.

Tablo 1. Erkek Grubu İçin Döndürülmüş Faktör Matrisi

\begin{tabular}{|c|c|c|c|c|}
\hline \multicolumn{5}{|l|}{ Erkek(n=564) } \\
\hline & \multicolumn{2}{|c|}{$\begin{array}{l}\text { Ortalama ve } \\
\text { Std S. }\end{array}$} & \multicolumn{2}{|c|}{ Bileşenler } \\
\hline & Ort. & SS & $\begin{array}{l}\text { Yak- } \\
\text { laşm } \\
\text { a }\end{array}$ & $\begin{array}{l}\text { Kaçın } \\
\text { ma }\end{array}$ \\
\hline $\begin{array}{l}\text { T4: Tartışmalı bir konu hakkında iyi bir tartışma } \\
\text { yapmaktan keyif alırım. }\end{array}$ & 3,92 & 1,17 & 0,748 & \\
\hline $\begin{array}{l}\text { T5: Bir soruna ilişkin görüşlerimi savunmaktan } \\
\text { hoşlanırım. }\end{array}$ & 4,16 & 1,06 & 0,741 & \\
\hline $\begin{array}{l}\text { T9: Bir tartışmanın gereklerini sağlayacak } \\
\text { yeteneğe sahibim. }\end{array}$ & 3,97 & 1,04 & 0,719 & \\
\hline $\begin{array}{l}\text { T2: Tartışmalı bir konuya ilişkin konuşurken } \\
\text { istekli ve enerjik olurum. }\end{array}$ & 3,80 & 1,16 & 0,712 & \\
\hline $\begin{array}{l}\text { T7: Tartışmayı heyecan verici fikirsel bir mey- } \\
\text { dan okuma olarak görürüm. }\end{array}$ & 3,63 & 1,25 & 0,647 & \\
\hline $\begin{array}{l}\text { T8: Bir tartışma sırasında etkili görüşler ortaya } \\
\text { koymada kendimi yetersiz görürüm. }\end{array}$ & 2,37 & 1,27 & & 0,697 \\
\hline $\begin{array}{l}\text { T10: Tartışmalı konulara girmekten kaçınmaya } \\
\text { çalışırım. }\end{array}$ & 2,89 & 1,39 & & 0,638 \\
\hline $\begin{array}{l}\text { T6: Benimle nadiren hemfikir olan insanlarla bir } \\
\text { arada olmayı çok istemem. }\end{array}$ & 2,87 & 1,29 & & 0,631 \\
\hline $\begin{array}{l}\text { T3: Biriyle tartışmayı bitirdiğimde, sinirli ve } \\
\text { üzgün hissederim. }\end{array}$ & 2,91 & 1,22 & & 0,601 \\
\hline $\begin{array}{l}\text { T1:Tartışmalı bir konuda, tartıştığım kişinin } \\
\text { hakkımda olumsuz bir izlenime kapılmasından } \\
\text { endişe duyarım. }\end{array}$ & 3,12 & 1,30 & & 0,415 \\
\hline
\end{tabular}


Tablo 2. Kadın Grubu İçin Döndürülmüş Faktör Matrisi

\begin{tabular}{|c|c|c|c|c|}
\hline \multicolumn{5}{|l|}{ Kadın(n=997) } \\
\hline & \multicolumn{2}{|c|}{$\begin{array}{l}\text { Ortalama } \\
\text { ve Std S. }\end{array}$} & \multicolumn{2}{|c|}{ Bileşenle } \\
\hline & Ort. & SS & $\begin{array}{l}\text { Ya } \\
\text { kl } \\
\text { aş } \\
\text { m } \\
\text { a }\end{array}$ & $\begin{array}{l}\text { Kaçı } \\
\text { nma }\end{array}$ \\
\hline $\begin{array}{l}\text { T2: Tartışmalı bir konuya ilişkin konuşurken istekli ve } \\
\text { enerjik olurum. }\end{array}$ & 3,42 & 1,18 & $\begin{array}{l}75 \\
5\end{array}$ & \\
\hline $\begin{array}{l}\text { T4: Tartışmalı bir konu hakkında iyi bir tartışma yap- } \\
\text { maktan keyif alırım. }\end{array}$ & 3,60 & 1,22 & $\begin{array}{l}, 74 \\
6\end{array}$ & \\
\hline $\begin{array}{l}\text { T9: Bir tartışmanın gereklerini sağlayacak yeteneğe sa- } \\
\text { hibim. }\end{array}$ & 3,64 & 1,16 & $\begin{array}{l}71 \\
3\end{array}$ & \\
\hline $\begin{array}{l}\text { T5: Bir soruna ilişkin görüşlerimi savunmaktan } \\
\text { hoşlanırım. }\end{array}$ & 4,13 & 1,01 & $\begin{array}{l}, 69 \\
6 \\
\end{array}$ & \\
\hline $\begin{array}{l}\text { T7: Tartışmayı heyecan verici fikirsel bir meydan okuma } \\
\text { olarak görürüm. }\end{array}$ & 3,38 & 1,27 & $\begin{array}{l}68 \\
5\end{array}$ & \\
\hline $\begin{array}{l}\text { T3: Biriyle tartışmayı bitirdiğimde, sinirli ve üzgün } \\
\text { hissederim. }\end{array}$ & 3,37 & 1,24 & & 631 \\
\hline $\begin{array}{l}\text { T8: Bir tartışma sırasında etkili görüşler ortaya koymada } \\
\text { kendimi yetersiz görürüm. }\end{array}$ & 2,37 & 1,19 & & 605 \\
\hline $\begin{array}{l}\text { T6: Benimle nadiren hemfikir olan insanlarla bir arada } \\
\text { olmayı çok istemem. }\end{array}$ & 2,86 & 1,24 & & ,592 \\
\hline $\begin{array}{l}\text { T10: Tartışmalı konulara girmekten kaçınmaya } \\
\text { çalışırım. }\end{array}$ & 2,97 & 1,27 & & ,587 \\
\hline $\begin{array}{l}\text { T1: Tartışmalı bir konuda, tartıştığım kişinin hakkımda } \\
\text { olumsuz bir izlenime kapılmasından endişe duyarım. }\end{array}$ & 3,17 & 1,21 & &, 541 \\
\hline
\end{tabular}

Tablo 1 ve 2 de görüldüğü üzere farklı zamanlarda yeterli sayıda farklı iki grup üzerinde uygulanan ölçeğin faktör yükleri benzer şekilde iki boyutta oluşmuştur. Elde edilen keşfedici faktör analiz bulguları ölçeğin geçerlemesinde ikinci aşama olan doğrulayıcı faktör analizine geçmemize olanak sağlamaktadır.

Doğrulayıcı faktör analizi ölçeğin kültürel farklılıklarda durumunu belirlemek maksadıyla uyum iyiliğini değerlerini veren biz analiz yöntemidir. Bu analizler ölçek geçerlemelerinin en önemli aşamasını 
oluşturmaktadır. Doğrulayıcı faktör analizinde (DFA) iki ayrı program kullanılmaktadır. Bunlar Lisrel ve Amos'tur. Bu çalışmada DFA için daha yeni bir uygulama olan Amos kullanılmıştır.

DFA'da ölçeklerin geçerlemesinde ölçeğin yapısına göre genellikle üç ayrı yöntem kullanılmaktadır. Bu yöntemlerin yapısı ölçeği oluşturan boyut sayısı, boyutların yapısı ve boyutların ana değişken ile olan ilişkilerine göre değişmektedir.

İlk yöntem benzer yönlü olan birden çok boyutlu ölçeklerde kullanılan faktörlerin eklenerek hangi faktörlü ölçeğin daha iyi uyum iyiliği verdiğini belirlemeye yönelik yöntemdir. Daha çok II. Düzey analizlerle yürütülen bu yöntem sonucunda en iyi uyum değerine ulaşmayı sağlayan boyutlar analize dâhil edilerek sonuca ulaşmaya çalışılır.

İkinci ve bu çalışmada uygulanan yöntem yine birden çok boyutlu ancak boyutların yönlerinin farklı olduğu ve bir bütünü birlikte tamamlamadıkları ölçeklerde kullanılmaktadır. Bu tarz ölçekler çoğunlukla birbirinden 180 derece farklı olan tutumları belirlemeye yönelik ölçeklerdir. Bu yöntemde boyutların farklılaşmasından dolayı I. Düzey analizler yapılarak faklı gruplarda analizler uygulanır ve benzer uyum iyiliği değerleri elde edilmeye çalışılmaktadır.

Üçüncü ve son yöntemde ise yukarıda sayılan iki yöntemde elde edilen uyumlu modeller bu değişkenle ilişkili bir başka değişkenle birlikte analize tabii tutulur. Yakınsak analiz olarak da ifade edilen bu yaklaşımda farklı gruplardan elde edilen uyumlu modellerin farklı bir değişken üzerinde benzer bir etkiye sahip olarak uyumluluklarını sürdürmeleri beklenmektedir.

Analiz sonuçlarında dikkat edilmesi gereken nokta ölçeğin bir bütün olarak değil ayrı ayrı kullanılması gerekliliğidir. Nitekim Yaklaşma(olumlu) ve kaçınma(olumsuz) gibi tam ters yönlü iki tutumu bir başlık altında toplayan tartışmacı tutum ölçeği boyutları ayrı ayrı kullanıldığında daha etkili sonuçlar verebilecektir. Aksi halde mantıksal ve teorik olarak hata oluşacaktır. 
Şekil 2. Kadın gruplar için I. Düzey DFA model

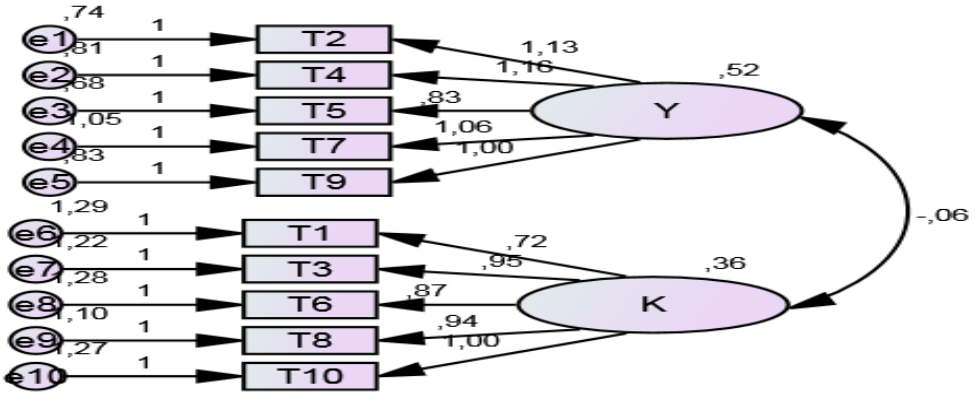

Bu çalışmada DFA ile elde edilen modeller Şekil 2 ve 3 'te sunulmuştur. Kadın (TTK) (Şekil 2) ve erkeklerde (TTE) (Şekil 3) elde edilen modellere ilişkin uyum iyiliği değerleri Tablo 3'te sunulmuştur. Tablo 3'te de görüldüğü gibi, kadın ve erkek gruplarına uygulanan I. düzey DFA analiz bulguları uyum iyiliği değerlerinin beklenen standartlarda ve benzer olduğunu göstermektedir.

\section{Şekil 3. Erkek gruplar için I. Düzey DFA modeli}

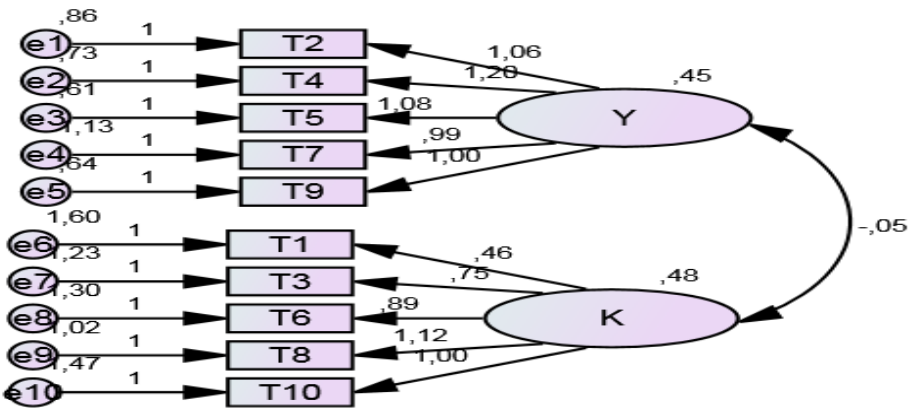


Tablo 3. Doğrulayıcı faktör analizi sonucunda ölçeklerin uyum iyiliği değerleri

\begin{tabular}{|l|l|l|l|l|l|l|l|l|l|}
\hline & $\mathbf{X}^{2}$ & $\mathbf{d f}$ & $\begin{array}{l}\text { CMIN/ } \\
\text { DF } \\
\mathbf{5}\end{array}$ & $\begin{array}{l}\text { GFI } \\
\mathbf{2}\end{array}$ & $\begin{array}{l}\text { AGF } \\
\mathbf{2} \mathbf{8 0}\end{array}$ & $\begin{array}{l}\text { CFI } \\
\mathbf{2 . 9 0}\end{array}$ & $\begin{array}{l}\text { NFI } \\
\mathbf{2 . 9 0}\end{array}$ & $\begin{array}{l}\text { TLI } \\
\mathbf{2 . 9 0}\end{array}$ & $\begin{array}{l}\text { RMSEA } \\
\leq .08\end{array}$ \\
\hline TTK & 325,8 & 68 & 4,7 & 0.96 & 0.83 & 0.91 & 0.90 & 0.90 & 0.04 \\
\hline TTE & 325,8 & 68 & 4,7 & 0.96 & 0.93 & 0.91 & 0.90 & 0.90 & 0.04 \\
\hline
\end{tabular}

Not: Uyum iyiliği değer aralıkları "kabul edilebilir" standartlara göre düzenlenmiştir.TTK=tartışmacı tutum kadın, TTE=tartışmacı tutum erkek.

\section{Tartışma ve Sonuç}

Yürütülen çalışmada uluslararası yazında otuz altı yıldır iletişim başta olmak üzere bireyler arası ilişkiler, eğitim, aile ilişkileri, kültürlerarası etkileşim-psikoloji ve örgütsel psikoloji gibi alanlarda kullanılan bir kavram olan tartışmacı tutum değişkeni ele alınmıştır. Çalışmada tartışmacı tutum değişkeninin ölçülmesine yönelik olarak geliştirilmiş 20 maddelik tartışmacı tutum ölçeğinin (Türkçe yazında sık kullanımı olmayan) 10 maddelik kısa formunun Türkçe güvenilirlik ve geçerlilik analizleri üniversite öğrencilerinden oluşan bir örneklem üzerinde gerçekleştirilmiştir.

Çalışmada örneklem kadın ( $n=997)$ ve erkek $(n=564)$ olmak üzere iki ayrı alt gruba ayrılmıştır. Çalışma içerisinde kapsamlı bir şekilde de açılandığı üzere tartışmacı tutum ölçeği yaklaşma ve kaçınma olmak üzere iki alt boyuttan oluşmaktadır. Tartışmacı turumu ölçmeye çalışan ölçeği oluşturan iki boyut olumlu ve olumsuz yönde tartışmacı tutumu belirlemeye çalışmaktadır.

Erkekler için ölçeğin yaklaşma boyutu ortalama, standart sapma değerleri ve madde yükleri sırasıyla incelendiğinde boyutların beklenen şekilde dağıldığı ve benzer faktör yüklerine sahip oldukları görülmüştür. Madde ortalamalarından hareketle erkek ve kadın katılımcıların tartışmacı tutumlarında yaklaşmacı tutumun kaçınmacı tutumdan nispeten daha güçlü olduğu sonucuna ulaşmak mümkündür. 
Kısaltılmış Tartışmacı Tutum Ölçeği'nin güvenirliğini test etmede iç tutarlılık yöntemi tercih edilmiştir. Ölçeği oluşturan iki alt boyutun iç tutarlığını gösteren Cronbach Alphanın her iki grup için.71olduğu görülmüştür. Elde edilen bu değerlerin Tartışmacı Tutum Ölçeği'nin 10 maddelik kısa sürümü kullanan araştırmalarda ki değerler ile benzerlik gösterdiği görülmüştür (Öncü çalışmalarda Cronbach Alpha değerleri, 1982'de Rancer tarafından .73; 1997' de Martin ve Anderson tarafından .80 ve 2000' de Myers ve Knox tarafından .86 olarak bulunmuştur. Yine alanda yapılan diğer pek çok çalışmada güvenilirlik katsayısı .70-.85 arasında belirlenmiştir.Daha kapsamlı bilgi için bkz. Anderson ve Martin, 1999; Myers, 1998; Myers \& Rocca, 2000).

Ölçeğin yapısal geçerliliğini test etmek amacıyla keşfedici ve doğrulayıcı faktör analizleri yapılmıştır. Keşfedici faktör analizi sonucunda hem kadın hem de erkek öğrenci örnekleminde Kısaltılmış Tartışmacı Tutum Ölçeği'nin orijinaline uyumlu iki alt boyutlu hali (yaklaşma ve kaçınma boyutu) doğrulanmıştır.

Doğrulayıcı faktör analizi sonucunda da kadın ve erkek örneklem grubu katılımcılarında uyum iyiliği değerleri eşik değerler ve üzerinde gerçekleşmiş, bu değerler de ölçeğin iki boyutlu yapısını doğrulamıştır. Ancak çalışmamızı farklı kılan nokta, yapılan DFA'da I. Düzeyanalizde iki alt boyutu ayrı ayrı biçimde ele alan analizlerin kullanılmasıdır. Nitekim ölçekte zit yönde iki boyut teorik olarak tartışmacı tutumu tamamlamasına rağmen pratik olarak ölçeğin her bir boyutunun ayrı ayrı kullanılması zorunluluğu ortaya çıkmıştır. Bu kapsamda Tartışmacı tutum ölçeğinin II. düzey DFA modelinin yani bütünleşik halinin yapısal eşitlik modellerinde kullanılması mümkün değildir. Bu kapsamda yapılan analiz ve açıklamaların işaret ettiği gibi, Tartışmacı Tutum Ölçeği boyutları yaklaşmacı ve kaçınmacı tutumlar olarak ayrı ayrı kullanılarak araştırma modelleri tasarlanmalıdır.

Her çalışmada olduğu gibi yürütülen bu çalışmanın da bazı sinırlılıkları bulunmaktadır. Öncelikle Kısaltılmış Tartışmacı Tutum Ölçeği ile ilgili elde edilen güvenilirlik ve geçerlilik analizi bulguları, çalışmanın katılımcıları bağlamında sınırlılık göstermektedir. Şöyle ki, çalışmanın verileri sadece üniversite eğitimini sürdüren yaş ve eğitim düzeyi açısından göreli olarak homojen bir gruptan elde edilmiştir. Bu sınırlılı̆̆ı gidermek üzere, gelecekte yapılacak çalışmalar öğrencilerin yanı 
sıra farklı sektörlerde faaliyet gösteren kurumlarda farklı mevkilerde, farklı yetkinlik alanlarında çalışanlardan da veriler sağlayabilir. Çalışmanın bir diğer kısıdı araştırmanın boylamsal olmamasıdır. Her ne kadar farklı gruplara farklı zamanlarda anket uygulansa da aynı gruba farklı zamanlarda yapılacak uygulamaların nispeten farklılaşabileceği düşünülmektedir. Araştırmanın son kısıdı ise farklı bir bağımlı değişken kullanılarak uygulanan yakınsak geçerleme süreci yerine daha kısa olan geçerleme yönteminin kullanılmış olmasıdır. Bu eksiklik -ki bu tam bir eksiklik ya da hata olarak nitelendirilemez- farklı gruplarda farklı zamanlarda uygulanan anket ile kısmen telafi edilmeye çalışılmıştır.

Tartışmacı tutum ölçeğinin kısa formu özellikle nadiren kullanıldığı ulusal yazında kurgulanacak örgütsel davranışla ilişkili çalışmalarda tercih edilebilir. Bu alanda tartışmacı tutum değişkeni; örgütsel muhalefet, örgütsel seslilik, kültürel düzey (bireycilik-toplulukçuluk vb.) ve bireysel düzey (bağımlı-bağımsız benlik kurgusu vb.) kültürel değişkenler, proaktif kişilik, iş tatmini ve örgütsel sosyalleşme gibi örgütsel davranış konularıyla korelatif, deneysel, boylamsal tasarıma uygun olarak kurgulanabilir. Bunlara ilave olarak tartışmacı tutum değişkeni,sayılan örgütsel davranış konularıylateorik altyapıya bağlı kalınarak aracılık ve düzenleyicilik etkileri çeşitli modellemeler ile çalışılabilir. 


\title{
EXTENDED ABSTRACT
}

\section{The Analysis of Turkish Validity and Reliability on the Short Version of Argumentativeness Scale

\author{
Ömer Turunç - H. Bahadır Eser - Mehmet Dinç \\ Süleyman Demirel University
}

In communication literature pattern, consistency and differences in message receiving and sending behaviors are expressed by the concept of "communication personality characteristics". In the literature, it was argued that communication orientations were more appropriate for investigating communicative behaviors because they were more restricted areas of message production, as opposed to personality trait structures. From this point of view, verbal aggressiveness and argumentativeness are considered as communication oriented (personality) features. The argumentativeness was generally defined as a stable personality trait. This personality trait influences how argumentative individuals respond to events, and identifies those who are more likely to participate in interpersonal discussions, and who consider the debate as a built-in activity in proving and reasoning. The communicative personality variable, known as argumentativeness, has attracted interest in the international literature for about 36 years in a wide range from education to romantic relations, family communication and organizational communication. However, being able to do specifical way argumentativeness of the empirical studies in organizational behavior research in Turkey is undergoing appropriate scale with psychometric competence in this regard. Based on this requirement, the aim of this study is to test the validity of the 10-item short version of the Argumentativeness Scale, 20-item in the original and developed by Infante and Rancer (1982), by adapting to Turkish and Turkish culture.

The validity study of the Argumentativeness Scale was carried out within the scope of five main processes. These processes consist of stages as determining the scale, determining the sample, translating, analyzing, 
and comparing and evaluating. At these stages, it is tried to use the most effective analysis and comparison methods based on universal and current applications. The study was conducted in Süleyman Demirel University Faculty of Economics and Administrative Sciences in Isparta. In this faculty, face-to-face surveys were conducted with the undergraduate students who were educated in 11 different departments. The scale was applied to two different groups and the validity was determined. The method followed by Brislin et al. (1973) was used to test the construct validity of the short version of Argumentativeness Scale.

In this study, it was tried to complete the scale validation studies by making comparisons with factor analysis and internal consistency analyzes and test-retest analysis in two separate samples. Firstly, exploratory factor analysis was performed. After that, Amos was used for confirmatory factor analysis (CFA).

In the present study, the argumentativeness variable, which is a concept used in fields such as interpersonal relations, education, family relations, intercultural interaction-psychology and organizational psychology in the international literature for thirty-six years has been discussed. In this study, reliability and validity analyzes of the 20-item argumentative attitude scale of the 10-item short form of Turkish version (not commonly used in Turkish literature) were carried out on a sample of university students. The study was divided into two subgroups: female $(n=997)$ and male $(n=564)$. The argumentativenes scale was consisted of two subscales, approaching and avoiding. These two dimensions, which try to measure argumentativeness and make up the scale, was determined the positive and negative argumentativeness. The mean size, standard deviation values and item loadings of the scale for males and females were found to be distributed in the expected way and they had similar factor loads. Based on item means, it is possible to conclude that the approaching dimension of the male and female participants is relatively stronger than the avoidant dimension.

The internal consistency method was used to test the reliability of the Short Version of Argumentativeness Scale. It was found that Cronbach Alpha of two sub-dimensions of the argumentativeness scale was .71 for both groups. In order to test the structural validity of the scale, exploratory 
and confirmatory factor analyzes were performed. As a result of the exploratory factor analysis, two sub-dimensions (approaching and avoiding dimension) of the Short Version of Argumentativeness Scale, which were compatible with the original, were confirmed in both female and male students. As a result of confirmatory factor analysis, the goodness of fit values of the female and male sample group were above the threshold values and these values confirmed the two-dimensional structure of the scale. However, the point that makes this study different is the use of the analyzes which take two sub-dimensions separately in the CFA. As a matter of fact, although the two dimensions in the opposite direction have completed the theoretical argumentativeness, it has become practically necessary to use each dimension of the scale separately. In this context, it is not possible to use the argumentativeness scale in the second-order DFA model, ie the integrated version of structural equation models. As the analysis and explanations made in this context point out, research models should be designed by using Argumentativeness Scale dimensions as approaching and avoiding attitudes separately.

\section{Kaynakça/References}

Alcala, C.G. (2012). The development and testing of the spanish-language versions of the argumentativeness and verbal aggressiveness scales. Yayımlanmamış Yüksek Lisans Tezi, Akron Üniversitesi.

Anderson, C.M. ve Martin, M.M. (1999). The relationship of argumentativeness and verbal aggressiveness to cohesion, consensus and satisfaction in small groups. Communication Reports, 12, 21-31.

Avtgis, T.A. ve Rancer, A.S. (2002). Aggressive communication across cultures: a comparison of aggressive communication among United States, New Zealand and Australia. Journal of Intercultural Communication Research, 31(2), 191-200.

Avtgis, T.A., Rancer, A.S., Kamjeva, P.A. ve Chorry, R.M. (2008). Argumentative and aggressive communication in bulgaria: Testing for conceptual and methodological equivalence. Journal of Intercultural Communication Research, 37, 17-24. 
Bayer, C. ve Cegala, D. (1992). Traits verbal aggressiveness and argumentativeness: relations with parenting style. Western Journal of Communication, 56, 301-310.

Blickle, G. (1995). Conceptualization and measurement of argumentativeness: A decade later. Psychological Reports, 77, 99-110.

Brislin, R. W., Lonner, W. J., Thorndike, R. M. (1973).Cross-cultural research methods, New York: John Wileyve Sons Pub.

Cann, A., Norman, A.M., Welbourne, J.L. ve Calhaun, L.G. (2008). Attachment styles, conflict styles and humour styles: interrelationships and associations with relationship satisfaction. European Journal of Personality, 22, 131-146.

Croucher, S.M., Oommen, D., Hicks, M.V., Holody, K.J., Anarbeava, J., Yoon, K., Spencer, A., March, C. ve Aljahli, A.I. (2010). The effects of self-construal and religiousness on argumentativeness: a crosscultural analysis. Communication Studies, 61, 135-155.

Croucher, S.M., DeMaris, A., Diers-Lawson, A.R. ve Roper, S. (2017). Selfreporting and the argumnetativeness scale: an emprical examination. Argumentation, 31, 23-43.

Daly, J.A. (1987). Personality and interpersonal communication: Issues and directions. İçinde J.C. McCroskey ve J.A. Daly (Eds.), Personality and Interpersonal Communication, (pp. 13-41). Newbury Park, CA:Sage.

Hamilton, M.A. ve Mineo, P.J. (2002). Argumentativeness and its effect on verbal aggressiveness: a meta-analytic review. İçinde M. Allen, R.W. Preiss, B.M. Gayle ve N. Burrell (Eds.), Interpersonal Communication Research: Advances through Meta-Analysis(pp. 281-314). Mahwah, NJ: Lawrance Erlbaum.

Hinkin, T. (1995). A review of scale development practices in the study of organizations. Journal of Management, 21 (5), 967-988.

Infante, D.A. (1981). Trait argumentativeness as a predictor of communicative behavior in situatins requiring argument. Central States Speech Journal, 32, 265-272.

Infante, D.A. (1987). Aggressiveness. İçinde J.C. McCroskey ve J. A. Daly (Eds.), Personality and Interpersonal Communication(pp. 157-192). Newbury Park, CA: Sage. 
Infante, D.A. (1988).Arguing Constructively Prospect Heights, IL:Waveland Press.

Infante, D.A. (1989). Response to high argumentatives: message and sex differences. Southern Communication Journal, 54, 159-170.

Infante, D.A., Anderson, C.M., Martin, M.M., Herington, A.D. ve Kim, J. (1993). Subordinates' satisfaction and perceptions of superiors' compliance-gaining tactics, argumentativeness, verbal aggressiveness and style. Management Communication Quarterly, 6, 307-326.

Infante, D.A. ve Gorden, W.I. (1987). Superior and subordinate communication profiles: implications for independent-mindedness and upward effectiveness. Central States Speech Journal, 38, 73-80.

Infante, D.A. ve Gorden, W.I. (1989). Argumentativeness and affirming communicator style as a predictors of satisfaction/dissatisfaction with subordinates. Communication Quarterly, 37, 81-90.

Infante, D.A. ve Gorden, W.I. (1991). How employees' see the boss: test of an argumentative and affirming model of supervisors' communicative behavior. Western Journal of Communication, 55, 294-304.

Infante, D.A. ve Rancer, A.S. (1982). A conceptualization and measure of argumentativeness.Journal of Personality Assessment, 46, 72-80.

Infante, D.A. ve Wigley, C.J. (1986). Verbal aggressiveness: an interpersonal model and measure. Communication Monographs, 53, 61-69.

Infante, D.A., Rancer, A.S. ve Womack, D.F. (2003). Building Communication Theory, (4th Edition). Prospect Heights, IL: Waveland Press.

Infante, D.A. ve Rancer, A.S. (1996). Argumentativeness and verbal aggressiveness: a review of recent theory and research. İçinde B. Burleson (Ed.), Communication Yearbook(Vol. 19, pp. 319-351). Thousand Oaks, CA: Sage.

Infante, D.A., Rancer, A.S. ve Wigley, C.J. (2011). In defense of the argumentativeness and verbal aggressiveness scales.Communication Quarterly, 59, 145-154.

Infante, D.A., Step, M.M. ve Horvath, C.L. (1997). Counterattitudinal advocacy: when high argumentatives are more persuasible?. Communication Research Reports, 14, 79-87.

Kotowsky, M.R., Levine, T.R., Baker, C.R. ve Bolt, J.M. (2009). A multitrait - multimethod validity assessment of the verbal aggressiveness 
and argumentativeness scales.Communication Monographs, 76(4), 443-462.

Johnson, A.J., Averbeck, J.M., Kelley, K.M. ve Liu, S.J. (2011). When serial arguments predict harm: examining the influences of argument function, topic of the argument, perceived resolvability and argumentativeness. Argumentation ve Advocacy, 47, 214-227.

Kaya, O.N. ve Kılıç, Z. (2008). Development of elemantary school students argumentativeness in science courses.Ahi Evran Üniversitesi Kırşehir Ĕ̆itim Fakültesi Dergisi (KEFAD), 9(1), 87-95.

Levine, T.R. ve Kotowsky, M.R. (2010). Measuring argumentativeness and verbal aggressiveness: psychometric concerns and advances. İçinde T.A. Avtgis ve A.S. Rancer (Eds.), Arguments, Aggression and Conflict: New Directions in Theory and Research (pp: 67-81). New York: Taylor ve Francis.

Limon, M.S. ve La France, B.H. (2005). Communication traits and leadership emergence: examining the impact of argumentativeness, communication apprehension and verbal aggressiveness in work groups. Southern Communication Journal, 70, 123-133.

Martin, M.M. ve Anderson, C.M. (1997). Aggressive communication traits: how similar are young adults and their parents in argumentativeness, assertiveness and verbal aggressiveness. Western Journal of Communication, 61(3), 299-314.

Myers, S. A. (1998). Instructor socio-communicative style, argumentativeness, and verbal aggressiveness in the college classroom. Сотmunication Research Reports, 15, 141-150.

Myers, S. A.,ve Rocca, K. A. (2000). Perceived instructor argumentativeness, verbal aggressiveness and student participation in the college classroom. Manuscript Under Review. Scott A. Myers ve Ronda.

Myers, S. A.,L. Knox (2000).Perceived instructor argumentativeness and verbal aggressiveness and student outcomes.Communication Research Reports, 17 (3), 299-309.

Öztürk, M. (2013). Argümantasyonun kavramsal anlamaya, tartışmacı tutum ve öz-yeterlik inancına etkisi. Yayınlanmamış Yüksek Lisans Tezi, Pamukkale Üniversitesi Eğitim Bilimleri Enstitüsü. 
Rancer, A.S., Baukus, R.A. ve Infante, D.A. (1985). Relations between argumentativeness and belief structures about arguing.Communication Education, 34, 37-47.

Rancer, A.S., Kosberg, R.L. ve Baukus, R.A. (1992). Beliefs about arguing as predictors of trait argumentativeness: 1mplications for training in argument and conflict management.Communication Education, $41,375-387$.

Rancer, A.S. (2004). Argumentativeness, verbal aggressiveness and persuasion. İçinde J.S. Seiter ve R.H. Gass (Eds.), Perspectives on Persuasion, Social Influence and Compliance-Gaining (pp. 113-131). Boston: Allyn ve Bacon.

Rancer, A.S. (1998). Argumentativeness. İçinde J.C. McCroskey, J.A. Daly, M.M. Martin ve M.J. Beatty (Eds.), Communication and Personality: Trait Perspectives(pp. 149-170). Cresskill, NJ: Hampton Press.

Rancer, A.S. ve Avtgis, T.A. (2006). Argumentative and Aggressive Communication: Theory, Research and Application.Sage Publications, Inc., Thousand Oaks: California.

Seibold, D. ve Meyers, R. (1986). Co-participant perceptions of information - gathering interviews: implications for teaching interviewing skills. Communication Education, 34, 106-118.

Stewart, R. ve Roach, K. (1998). Argumentativeness and the theory of reasoned action. Communication Quarterly, 46, 177-193.

Suzuki, S. ve Rancer, A.S. (1994). Argumentativeness and verbal aggressiveness: testing for conceptual and measurement equivalence across cultures. Communication Monographs, 61, 256-279.

Suzuki, S. (2011). Trait and state approaches to explaining argument structures. Communication Quarterly, 59, 123-143.

Tabachnick, B.,ve Fidell, L. (2012). Fidel], LS (1989). Using Multivariate Statistics. London: Pearson.

Terlip, L. (1989). An examination of the relationship between type a behavior, verbal aggression and argumentativeness. Unpublished Dissertation. The University of Oklahoma, Norman. 
Ek 1: Tartışmacı Tutum Ölçeği Kısa Formu

\begin{tabular}{|c|c|c|c|c|c|}
\hline $\begin{array}{l}\text { Aşağıda birtakım ifadeler verilmektedir. Bu ifadelerin sizi } \\
\text { ne oranda yansıttığını ya da yansıtmadığını "Hiçbir Za- } \\
\text { man"'dan, “Her Zaman "'a doğru işaretleyerek belirtiniz. }\end{array}$ & 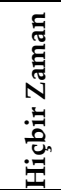 & 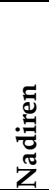 & $\begin{array}{l}\text { స్ } \\
\text { Ф̃ }\end{array}$ & $\begin{array}{l}\breve{y} \\
\overrightarrow{5} \\
\overrightarrow{5}\end{array}$ & 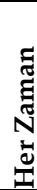 \\
\hline $\begin{array}{l}\text { 1. Tartışmalı bir konuda, tartıştı̆̆ım kişinin hakkımda } \\
\text { olumsuz bir izlenime kapılmasından endişe duyarım. }\end{array}$ & 1 & 2 & 3 & 4 & 5 \\
\hline $\begin{array}{l}\text { 2. Tartışmalı bir konuya ilişkin konuşurken istekli ve en- } \\
\text { erjik olurum. }\end{array}$ & 1 & 2 & 3 & 4 & 5 \\
\hline $\begin{array}{l}\text { 3.Biriyle tartışmayı bitirdiğimde, sinirli ve üzgün } \\
\text { hissederim. }\end{array}$ & 1 & 2 & 3 & 4 & 5 \\
\hline $\begin{array}{l}\text { 4. Tartışmalı bir konu hakkında iyi bir tartışma yapmak- } \\
\text { tan keyif alırım. }\end{array}$ & 1 & 2 & 3 & 4 & 5 \\
\hline 5. Bir soruna ilişkin görüşlerimi savunmaktan hoşlanırım. & 1 & 2 & 3 & 4 & 5 \\
\hline $\begin{array}{l}\text { 6. Benimle nadiren hemfikir olan insanlarla bir arada } \\
\text { olmayı çok istemem. }\end{array}$ & 1 & 2 & 3 & 4 & 5 \\
\hline $\begin{array}{l}\text { 7. Tartışmayı heyecan verici fikirsel bir meydan okuma } \\
\text { olarak görürüm. }\end{array}$ & 1 & 2 & 3 & 4 & 5 \\
\hline $\begin{array}{l}\text { 8. Bir tartışma sırasında etkili görüşler ortaya koymada } \\
\text { kendimi yetersiz görürüm. }\end{array}$ & 1 & 2 & 3 & 4 & 5 \\
\hline $\begin{array}{l}\text { 9. Bir tartışmanın gereklerini sağlayacak yeteneğe sa- } \\
\text { hibim. }\end{array}$ & 1 & 2 & 3 & 4 & 5 \\
\hline 10. Tartışmalı konulara girmekten kaçınmaya çalışııım. & 1 & 2 & 3 & 4 & 5 \\
\hline
\end{tabular}

\section{Kaynakça Bilgisi / Citation Information}

Turunç, Ö., Eser, H. B. ve Dinç, M. (2018). Tartışmacı tutum ölçeği kısa formunun Türkçe geçerlilik ve güvenilirlik analizi. OPUS-Uluslararası Toplum Araştırmaları Dergisi, 9(16), 731-759. DOI: 10.26466/opus.480175 